\title{
Emerging Female Voices and Child Marriage Reforms in Early Twentieth Century
}

\section{Manish Sharma}

Swami Shraddhanand College, University of Delhi

Email: sr.manish@gmail.com
INTERNATIONAL JOURNAL OF HISTORI-

CAL INSIGHT AND RESEARCH

E-ISSN: 2454-5600

Double Blind Peer Reviewed Journal

URL: http://ijhir.qtanalytics.in

\section{ABSTRACT}

Age long custom of Child Marriage could not be challenged in nineteenth century because neither reformer did have shastric evidences nor organized female voice opposed it, except sporadic cases. The main argument of this paper is that the first half of Twentieth century witnessed active participation of organized women of India, which raised their questions themselves and determined the enactment of the Child Marriage Restraint Act in 1929. Simultaneously, this paper also aims to contradict an idea that towards the end of Nineteenth century women's question was disappeared from agenda of public debates. I have used Government of India official papers, journals, contemporary books both in Hindi and English.

\section{KEY WORDS}

Women, Female Voices, Child Marriage, Nationalist, Feminist

In the beginning of twentieth century, India observed active participation of women in political and social life of the country through several women's organizations both at the provincial and national level which led to consolidation of Female Voices. In contrast to nineteenth century, these organizations raised the question of women from the stand-point of women and determined the enactment of the Child Marriage Restraint Act (Henceforth CMRA), popularly known as Sarda Act, in 1929. Moreover, the struggle and the collaboration with western feminists' interference particularly American and British strengthen the voice of Indian women which began to echo in the first half of twentieth century. Although, newly emergent women's movement in India dealt with the various wrongs of Indian womanhood like the Pardah, enforced widowhood, the Devdasi system, Women's education, and last but not the least the age long custom of Child Marriage, yet the passage of Sarda Act or the CMRA and its relationship with emerging Female Voice has not been fully developed.

Age long custom of Child Marriage was not challenged in nineteenth century because neither reformers did have evidences from shastras nor organized female voices opposed it, except sporadic cases. The famous case of RakhmaBai, towards the close of nineteenth century, was the grand act of defiance where a woman, married in childhood, challenged the basic patriarchal notion of subordination of a wife to her husband. She also, breached the notion of the sanctity of the Hindu marriage and role of a 
wife therein. she also, defied the colonial law of the restitution of conjugal rights. ${ }^{1}$

There was some change in the public articulation of such dissent to one of the core institution of Hindu patriarchy Marriage. That produced woman after woman like RakhmaBai, Pandita Ramabai. By the turn of the nineteenth century Pandita RamaBai was a famous as well as most controversial woman. ${ }^{2} \mathrm{~A}$ woman throughout had never remarried the worked for the cause of the woman throughout the life. Hence, RamaBai was considered the first representative of Indian female voice. Not only this, she established connections with foreign feminist circle to secure as much as moral and ideological support for her work.

However, Indian female voice took almost thirty years to be organized following the enactment of the Age of Consent Act in 1891. Around the World War $\mathrm{I}^{3}$ (1914-18) three all India women organizations were established which endorsed the campaign for Child Marriage Reforms.

The Earliest was Women's India Association (WIA) which was organized in Madras, (present day Chennai) in 1917 by two British theosophists, Dorothy Jinarajadasa and Margaret Cousin. (WIA) expressed its views on the urgent need of reforms including Child Marriage reforms through its official journal 'StriDharma'. The first lady president of the Indian national Congress Annie Beasant was the first president of (WIA). ${ }^{4}$

The next advocate was National Council of women in India (NCWI) was founded in $1925 .^{5}$

\footnotetext{
${ }^{1}$ Sudhir Chandra, Enslave Daughters: Colonialism, Law, Women's Rights, (Delhi, Oxford University Press, 1998)

2 Uma Chakravarty, Rewriting History : Life and Times of Pandita RamaBai, (New, Kali for Women, 1998)

3 Barbara Ramusack, “Women's Organizations and Social Change :The Age of Marriage Issue in
}

This council was the coordinating body for five provincial councils in Bombay (Present day Mumbai), Bangal, Burma, Bihar Orrisa, and Delhi. Essentially, the (NCWI) was based in Bombay and was affiliated to international council of women. Maharani ChimnaBai of Baroda was the first president of the (NCWI). She accentuated the "need of a campaign for increasing age of Consent and the Marriage until there was revolution in social practices". Above all, the Sarda Act was reviewed by Maharani ChimnaBai in 1929 who considered it as an opportunity to permit better education for woman and greater equality within life structure. ${ }^{6}$

The third champion was the All-India Women's Conference (AIWC) which was initially set up in 1927 by Margret Cousin to formulate more appropriate educational programmed for women. It quickly expanded into a permanent association and addressed educational as well as social goals. The leadership of the (AIWC) included the elements from (NCWI) since Maharani of Baroda SMT. ChimnaBai was its first president. Moreover, Dorothy Jinarajadasa, Margaret Cousin, and Annie Beasant were active in (AIWC). Soon AIWC had emerged as the most active feminist proponent for Legislative reform of Age of Marriage and identified child marriage, Purdah, seclusion of women as the major constraint on the education of women. ${ }^{7}$

Thus, with the help of these women organizations and feminists' activists, the question of woman was redeployed in 1920's.

India", in Naomi Black and A.B. Cottrel eds.
Women and World Change, (London, Sage Publi-
cation, 1981) pp. 198-216
4 Ibid
5 Ibid
6 Ibid
7 Ibid

India", in Naomi Black and A.B. Cottrel eds. Women and World Change, (London, Sage Publication, 1981) pp. 198-216

4 Ibid

5 Ibid

${ }^{6}$ Ibid

Sharma, M. (2021). Emerging Female Voices and Child Marriage Reforms in Early Twentieth Century. International Journal of Historical Insight and Research, 7(1), 18-29.

https://doi.org/10.48001/ijhir.2021.07.01.003 
While studying the redeployment of the question of woman with reference to child marriage reform campaign, it is necessary to discuss Imperialist and Nationalist policies.

The momentous declaration of Secretory of State for India Montague in 1917 brought a dramatic shift in the Imperialist ideology. With this declaration, British official policy in India reorganized for the first time at least in principle, the development of self-governing institutions for India. Even though, the change and pace were in the government's hands, diehard Imperialists expressed their anxiety about the future of the British government in India because of these constitutional changes. ${ }^{8}$ It is noteworthy that representation for Indians in central Legislative assembly was extended only for Indian males. However, these constitutional reforms allowed Indian women to enter in State Legislative Assembly only.

Gandhi withdrew Non-cooperation Khilafat movement in favour of social reform works or constructive works in 1922. Moreover, Indian leaders engaged to co-ordinate with Indian $\mathrm{Na}$ tional Congress within the new constitutional frame-work in form of Government of India Act of 1919. This period also witnessed the consolidation of various rival forms of politics based on differences of cast, class, religion, and region within broader structure of anti-colonial struggle. $^{9}$

Sarojini Naidu was appointed as the first Indian lady president of the Indian National Congress its 1925. The Nehru Report', all party constitution in 1928, proposed the principle of equality on the basis of sexes. By the mid 1920's a very

\footnotetext{
${ }^{8}$ Sumit Sarkar, Modern India 1885-1947, (Delhi, Macmillan, 1983)

${ }^{9}$ Ibid

${ }^{10}$ I have taken this information from the introduction of Mrinalini Sinha edited Selections from Mother India. Katherine Mayo. (Delhi, Kali for Women, 1998) pp. 1-61
}

small part of Indian women secured the right to vote and to be elected to the provincial Legislature and the number of women in municipal councilors and Justices of peace especially in advanced provinces of Madras [present day Chennai] and Bombay [present day Mumbai] also increasingly raised. ${ }^{10}$

Indian female voices were endorsed by the leaders of Nationalist movement of India. Gandhi, through his various articles, published in (Young India), advocated laws for increasing the age of marriage and the age of Consent but emphasized on the cultivation of public opinion against the evil custom of child marriage in the favour of Women's Movement of India. He wrote in 1935 that women themselves should come forward against Child Marriage. ${ }^{11}$

Interestingly, the involvement of the women of India in the National life of the country significantly attracted the attention of the 'Simon commission ', set up to deliberate on constitutional changes. ${ }^{12}$ Simon commission commented on the development of the female voice in India in its report, "the beginning of a movement among a certain section of Indian women is one of the most encouraging signs of India's progress. ${ }^{13}$ Thus, 1920 's was an important period for the history of elite's women involvement in the public life of India.

The main protagonist of women's movement in India and the representative of emerging Indian female voice Dr. S. Muthu Lakshmi Reddy became the first women member of Madras Legislative Council. She was born in 1886, and became the first lady deputy President of Madras Legislative Council for the period of

\footnotetext{
11 Collected Works of Mahatma Gandhi, Vol 34.

12 British Government appointed this Commission to revise the Government of India Act 1919 but did not nominate none of the Indian member. Hence Indians protested on large scale.

${ }^{13}$ In Stri Dharma, October 1933, p. 628
}

Sharma, M. (2021). Emerging Female Voices and Child Marriage Reforms in Early Twentieth Century. International Journal of Historical Insight and Research, 7(1), 18-29.

https://doi.org/10.48001/ijhir.2021.07.01.003 
1926-30. Mrs. Reddy was politically active and resigned her seat of Madras Legislative Council as the protest against imprisonment of Mahatma Gandhi. She joined Indian National movement in 1930. Muthulakshmi had close relations with British India government and social reformers, and she was nominated as the member of 'Simon auxiliary Committee' to promote the cause of education of women. ${ }^{14}$

Muthulakshmi Reddy was leading medical practitioner who was specialized in disease of women and children. Reddy took an interest in women's issues and child welfare and led WIA and AIWC, where she initiated several resolutions for women and children such as suppression of immoral traffic in girls, child welfare, education for girls, and women maternity. Mrs. Reddy edited 'Stri-Dharma, a famous women's magazine and the official voice of WIA till 1940. She was also involved in health schools, aboliDevadasi system in Hindu temples. ${ }^{15}$

Mrs. Reddy had voiced her radical views in an article 'WHO IS A DESTITUTE WOMAN'16. She considered child marriage as the main cause of the sorrow of Indian women therefore, most urgent reforms were needed to prevent from this custom through Legislation. The Marriage should be restricted to those couples who were able to provide economic safety to their future family. Furthermore, the couples and their elders must register the marriages of a girl and a boy, wrote Muthulakshmi. ${ }^{17}$

In the 1920's, Emerging female voice of India denied to accept customary laws and demanded equality between men and women. Dr.

\footnotetext{
14 Bio Data of S. Muthulakshmi Reddy, Speeches and Writings, Vol-1, part-1,Muthulakshmi Reddy Papers Henceforth MRP

15 Ibid

16 Ibid

17 Ibid

18 Ibid
} tion of child marriage, and abolition of

S. Muthulakshmi voiced criticism against unequal customary laws and unequal moral standards on the platform of WIA and AIWC. ${ }^{18} \mathrm{Hindu}$ Men were exercising their customary laws or traditional rights to punish the wives on mere ground of suspicion of immorality. She argued ${ }^{19}$ that laws and penalties must be equal to men and women and both of them must be made equally responsible. Moreover, she asked parents to teach both their girls and boys the virtue of chastity was not only meant for girls but for boys also. Furthermore, she said that the men had to be chaste for expecting chastity in women. Dr. Reddy suggested that the parents needed to be taught both their girls and the boys the concept of equality in gender relations and this education of equality should be given not only in homes alone but schools and colleges also. Moreover, Cinema and Radio could play a major role to bring awareness to the society. ${ }^{20}$

Indian female voice in 1920's could not be kept indifferent from the waves of Indian National movement against British rule. The independent women's movement of India considered that India's freedom cannot be attaining by merely criticizing the existing government or any revolutionary method, rather, by attending to the fundamental problems within society. Hence, women tried to secure support both from Imperialists and Nationalist quarter. Female voice of India played major role in the development of argument in this case against child marriage through political petitioning. ${ }^{21}$ Women also learnt about the difficulties of collaborating with apparent well-wishers who was actually British government. The Female

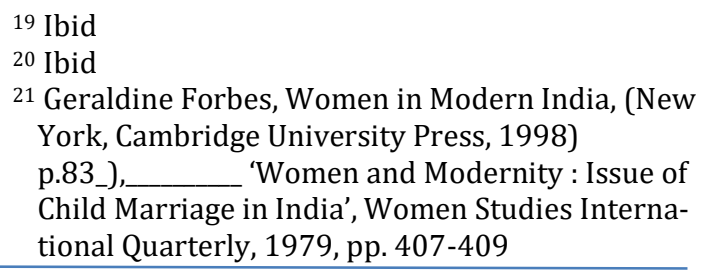

${ }^{19}$ Ibid

Sharma, M. (2021). Emerging Female Voices and Child Marriage Reforms in Early Twentieth Century. International Journal of Historical Insight and Research, 7(1), 18-29.

https://doi.org/10.48001/ijhir.2021.07.01.003 
voice of India got discouraged from the neglected behavior of British government towards the social issues of India. ${ }^{22}$

This frustration of the female voice was manifested in Dr. S. Muthulakshmi Reddy's speech in Indian social reform Conference held in Madras in December 1927 titled "Government's attitude towards Social reform". ${ }^{23}$ In this speech Reddy said "We all know that what the government's attitude was when Mr. Sarda's Child Marriage Bill was introduced. Even at this stage in spite of our meetings, in spite our memorials and petitions, the government member for home Honourable James Crerar brought a dilatory motion to delay such an urgent and good Legislation on the plea of religious neutrality, cannot enlighten the British government follow in the footsteps of the progressive native states even if they do not want to go against the orthodox feelings" even we the women have become discontented and have begun to crumble at the attitude of our government which is indifferent and unsympathetic to social Legislation."

The female voice warned the British government that mere abolition of 'sati' was not sufficient unless the evils of child marriage also not eradicated. This view was also expressed in Reddy's speech. She argued that the origin of sati was centered on the concept of love in which if one of them died the other could not bear the separation. In the changed condition the children were married not according to the concept of love but rather for cash and perseverance of age-old custom. Moreover, the girls and boys were excluded file in arranging their marriages and this ceremony was performed between the guardians of two families. Therefore, she asked for urgent Legislation against the evil custom of child marriage. ${ }^{24}$ She added

\footnotetext{
22 Ibid

${ }^{23}$ Speeches and Writings, Vol-2, part-2, MRP.

24 Ibid

25 Ibid
}

that sati abolition act of 1829 was not able to improve the status of women in society hence, Sarda's child marriage bill should be passed because the main attention of this bill was not only to protect the life of the girl but it aimed to save the life of those who were opposing this Bill (Orthodox section). ${ }^{25}$

The female voices of India played a significant role in the enactment of Sarda Bill. Although they could not convince the British government to nominate at least two lady members in all male Central Legislative Assembly to participate in a debate over Sarda Bill yet, they secured the nomination of one of its members, Mrs. Rameshwari Nehru, to the Age of Consent Committee. This committee was constituted by the British government to investigate the effects of pre-mature sexual intercourse inside and outside the marital relations, and need to raise the age of consent. ${ }^{26}$

(WIA) and (AIWC) passed resolutions in favour of higher age of marriage, what was adopted in Sarda Bill. It disagreed with Age of Consent Committee report which recommended 14 years as the minimum age of marriage for girls. Despite the disagreement, women's organizations took a compromising stand and asked female political leaders to support Sarda's Bill because that was not the proper time to discuss shortcomings or merits of the Bill. ${ }^{27}$

The orthodox section of the society also protested against the Sarda's Bill. They viewed this question from the point of view of perseverance of Ancient custom and text. Their view was criticized by emerging female voices in India. The female voice replied that those who were opposing Sarda's Bill did not discuss their own wives, mothers, sisters, and daughters, whether they wanted to merry at the tender

\footnotetext{
26 Government of India, Home Department Judicial, File No. 382/27

27 Speeches and Writings, Vol-2, Part-2, MRP
}

Sharma, M. (2021). Emerging Female Voices and Child Marriage Reforms in Early Twentieth Century. International Journal of Historical Insight and Research, 7(1), 18-29.

https://doi.org/10.48001/ijhir.2021.07.01.003 
age of 10 or $12 .{ }^{28}$ Only women had moral right to decide whether they wanted this bill or not. ${ }^{29}$ most powerful female voice Dr. S. Muthulakshmi Reddy argued that instead of marrying of the child at the tender age of 10 or 12 it was better to kill off the child, because if the child was killed then the clashes with religious laws will not emerge. ${ }^{30}$

Indian female voice refused to accept the argument of male opponents that education was the only medium to solve the question of women. They claimed that women's experience was sufficient to grapple with this issue. moreover, the opinion of women on this matter was fair evidence for government.

In answer to orthodox section quitted book "shigrabodha" which child marriage says that girls should me marry by the age of 10 years of age otherwise her parents and Brothers would go to hell. Indian feminist leaders replied that the no amount of shastras could restraint, early maternity, sexual intercourse with the girl of 10 or 12 years of age, and high rate of infant mortality". Moreover, women protested against the unequal marriages particularly the practice of marriage between child bride and old age groom. Bhagirathi Ammal argued that the selling of girls for money was equivalent to send the girl in hell and ironically the orthodox men were bothering hele after death and ignoring the living life. ${ }^{31}$

The decade of 1920's was the highest wave of legal reforms for women. They marked the first in which the necessity of changes in women's position acquired reasonable support from national movement hence the Sarda act can be viewed in contrast to controversy around the

\footnotetext{
28 Stri Dharma, September 1928, p.12

29 Ibid

30 MRP, Op.cit

31 Ibid
}

sati abolition act of 1829 , widow remarriage act of 1856, Age of Consent Act of 1891. This shift in nationalist opinion reflects the entry of women in feminists and nationalist organization, into the political sphere; a change in the class balance in the late colonial India; increasing prestige of bio medical sciences in the legal debates and medical jurisprudence. Above all, the initiative had come from nationalist block itself. 32

The medical and moral discourses, surrounding the CMRA, of 1929 demonstrated the modernist contour' of motherhood which signaled for the ideal female citizen of future independent India. The Assembly debates, newspapers, women's magazines, and the Report of Age of Consent Committee established the outline of the ideal feminine subject which was being assembled by the state Legislations during this period. The importance of women's organizations in the debates on age of marriage law of 1920 's manifested in way in which women were drawn in the discourse of modernity which tied into the nationalist cause.

In addition to the efforts of these women and their organizations in the support of The Sarda Act, the intervention from foreign feminists related to the question of women are also relevant for studying the Indian female voice in making of the Sarda act. these national women organizations also led to establishment of women's organizations at provincial level. Moreover, organized female voice of India in 1920 's had close relations with the women of princely states

However, the British feminists' activists had been existing in India since nineteenth century, it was in the beginning of twentieth century,

32 Judi Whitehead, Modernizing the Motherhood Archetype: Public Health Models and Child Marriage Restraint Act of 1929", in Patricia Oberai eds , Social Reform, Sexuality and the State, (New Delhi, Sage, 1996) pp. 187-210

Sharma, M. (2021). Emerging Female Voices and Child Marriage Reforms in Early Twentieth Century. International Journal of Historical Insight and Research, 7(1), 18-29.

https://doi.org/10.48001/ijhir.2021.07.01.003 
that an American lady, Marcus B. Fuller ${ }^{33}$ reviewed the condition of women in India, and the initiatives taken by Indian social reformers and the British government. The most significant aspect of Fuller's book was that it was endorsed and forwarded by Pandita RamaBai that shows the connection of foreign feminists with Indian female activists or Indian female voices.

Pandita RamaBai wrote in the introduction of the book that such books were needed because very few people in India were unaware of the sufferings of women because of age long customs upheld by religious leaders and laws. She blamed the social reformers for being ignorant of real condition of women and also pointed out that Indian women themselves did not realize the depth of degradation they were in. Indian women were reluctant to tell the truth before the world due to the consideration of the honour of the family and the nation. ${ }^{34}$

Even though, Fuller accepted that she had spent her much of the time in western India thus far the status of women in the society and the family could be generalized for whole of India. Since she came from America and did not know the customs and the languages of India, she could have exaggerated the wrongs with Indian womanhood. However, to avoid such charges, she had taken most of the information from Indian sources.

Fuller's work can be divided in to two parts. In the first part she has discussed various wrongs such as Purdah, enforced widowhood, Zenana, Female infanticide, the Devdasi system, Women's education, and the Child Marriage and etc. In the second fart, she reviewed the initiatives taken by the government and the reformers. The most significant aspect of the
Fuller's book was the remedies to grapple with these wrongs. She asked Indian women to be organized against these wrongs.

According to Fuller if the women themselves protest against the wrongs then the problems could be easily solved. She reacted against the missionary activities in view of the social reforms related to women "is it possible for one hundred fifty million women of this generation to hear the gospel" 35 therefore she said That the spread of education was the most effective means for the salvation of the women of India. $^{36}$

Thus, Fuller's book was an attempt to organize Indian female voice. even though She was American, took interest in the question of women from the Feminist perspective. However, organized female voice in India did not emerge in the beginning of twentieth century, yet, individually radical women did welcome Fuller's book. While Katherine Mayo's “Mother India was severely criticized by organized women's movement in 1920's.

Katherine Mayo, A Journalist from United States of America wrote Mother India in 1927, ${ }^{37}$ played significant role both in the development of women's movement of India and in passage of the Sarda Act. Mayo's Mother India was the principal factor that led to broad alliance amongst the reformers, the Revivalist, the Nationalists, and organized female voices of India. 38

Mayo considered that the backwardness of India stemmed not for political and economic causes but for religious and cultural ones. ${ }^{39}$ This served two important purposes, it countered Indian nationalist claims of Indian

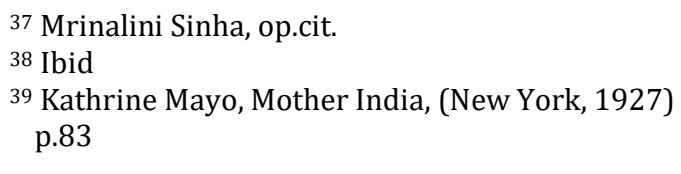

36 Ibid

Sharma, M. (2021). Emerging Female Voices and Child Marriage Reforms in Early Twentieth Century. International Journal of Historical Insight and Research, 7(1), 18-29.

https://doi.org/10.48001/ijhir.2021.07.01.003 
superiority in the realm of culture and spirituality over the material west; and it exempted the colonial rule from any responsibility for the social backwardness of India. ${ }^{40}$ Focusing the custom of child marriage, Mayo argued that the main cause for the degeneration of Hindu race was the wide prevalence of the custom of child marriage. this custom-made Indians mentally and physically weak and incapable of holding the responsibility of "Self-Rule". ${ }^{41}$

This book was published in 1927 when the issue of child marriage was widely debated; thus, it can be well-thought-out that. It had detailed account of the sufferings of child brides, harms of child marriage and pre-mature maternity; thus, it can be well-thought-out that Mayo's Mother India was the motivating factor in the passing of Sarda marriage Bill in October 1929. Hence mayo's book became important episode because of its historical settings. ${ }^{42}$

Mother India had to face severe criticism from both female voices and nationalist quarters the largest protest meeting was held in Calcutta [modern day Kolkata] town hall by leading female politicians of that time. ${ }^{43}$ The most powerful critique of Mayo's mother India was issued by Dr. S. Muthulakshmi Reddy on behalf of organized female voice of India. ${ }^{44}$

In comment on “Miss Mayo's book about Indians", Reddy argued that this book was replete with inaccuracies, misstatements and truth perverted ", and the most deplorable feature of book that the questions have been far away from the context to suit her purpose and has been given quite different colouring of her own". ${ }^{45}$ This book was widely read by British and American public and portrayed Indians as

\footnotetext{
${ }^{40}$ Mrinalini Sinha, op.cit, pp.1-61

${ }^{41}$ Katherine Mayo, op.cit, p.92

42 Mrinalini Sinha, op.cit, pp.1-61

43 Ibid

${ }^{44}$ Speeches and Writings, Vol-2, part-2, MRP

45 Ibid
}

"Semi- barbarous s" race deserve to be treated as slaves. The views expressed by Mayo in her book about Indians will have dangerous effects upon the conducts of the western towards Indians". ${ }^{46}$ Reddy invoked Indian women to engage themselves in the controversy around Mother India and added "until we gain strength by our unity there is no hope or salvation for Indians". ${ }^{47}$ To those who had asked not to waste time on this book She replied, "do not ask Swaraj be slave forever and do not communicate with west". 48

Nevertheless, Reddy admitted that Mayo's book had certain amount of truth like the untouchability, the rigid caste system, evils of early marriage and pre mature consummation, training of young girls for immoral purpose, emasculation of girl from father and husband's property, above all lack of women's education According to Reddy Mayo's book contains exaggeration, truths and half-truths though it had validity. ${ }^{49}$

Mother India faced criticism not only from Indian female voice and individual women but from Indian nationalists also. The nationalist critique was best represented in Gandhi's 'Drain Inspector Report' published in YOUNG INDIA on 15 September, 1927.50

Despite his busy schedule, Gandhi reviewed Mother India during his tour to Southern India. He argued "book was cleverly and powerfully written" "carefully chosen quotations give it the appearance of a truthful book" but Gandhi's impression was that this book was a report of "Drain inspector" send out with one purpose of opening and examining the drains of the country. Gandhi acknowledges her labour but at the

$$
\begin{aligned}
& 46 \text { Ibid } \\
& 47 \text { Stri Dharma, October 1927, p.18 } \\
& 48 \text { Speeches and Writings, Mrp, op.cit } \\
& 49 \text { Ibid } \\
& 50 \text { Collected Works of Mahatma Gandhi, Vol-34, } \\
& \text { pp. } 539-547
\end{aligned}
$$

Sharma, M. (2021). Emerging Female Voices and Child Marriage Reforms in Early Twentieth Century. International Journal of Historical Insight and Research, 7(1), 18-29.

https://doi.org/10.48001/ijhir.2021.07.01.003 
same time put the contentions that if she writes a book on America' social issues her facts will be close to challenge. Gandhi refused the analysis made by Mayo and argued that the Mayo behaves like both 'prosecutor' and' Judge' and preserve the facts perversely. He appealed that that this book for British and American people to warn them against believing this book. ${ }^{51}$

Thus, the female voices and the national critique of Mother India brought both of them together on the issue of child marriage and asked for urgent need of Legislative reforms which certainly does not need help of foreign government but the men and women of India who understands the realty of India. Apart from contrast and collaboration between individual and organized Indian female voice and western female voice against the custom on the question of women in India some foreign feminist against child marriage and need to Legislation against this custom. 52

In this connection British feminist E. Rathbone, president of the national union of society for equal citizenship emerged in the wake of the Mother India controversy as the most influential voice in Britten in favour of taking up Imperial responsibility for the women of India. She was inspired by Mayo and spent the next decade (from 1931 onwards) and investigating the cause of Indian women. Rathbone used the revelations in Mother India to impress upon women's organizations and the British parliament, the significance of Sarda Act in Britten as an example to India, which urgently needed the benefits of such Legislative measure ${ }^{53}$.

Representatives of Indian female voice maintained the distance not only the contents of Mother India but from Rathbone also. Because of latter's explicit alliance with Mayo's Mother India. For instance, the tension between Indian

\footnotetext{
51 Ibid

52 Mrinalini Sinha, Op.cit

53 Ibid
}

female voice and Rathbone's efforts to assume responsibility for Indian women in total ignorance of initiatives of Indian women themselves led to Indian female voice which severely opposed Rathbone's stand. This conflict was conspicuous between Rathbone and Dhanwantri Ramarao, active activist of Indian female voice met with Rathbone in October 1929 in a conference in London. ${ }^{54}$

Above all, Indian female voice used the platform by other women organizations in Britten to utilize it to strengthen Indian female voice ; these women's organizations in Britten had recognized Indian female voice British commonwealth league, A forum for publicizing their position during Mother India controversy, founded by Australian feminist in Britten, provided representatives of the Indian women's movement in London, like Dorothy Jinarajadasa, Mrinalini Sen, Dhanwantri Ramarao and others. ${ }^{55}$

this is important to bear in mind that Rathbone changed her earlier position in her book, Child Marriage; the Indian Minotaur (1935). her book shared the notion of the causes and effects of child marriage Mayo's Mother India but she neither let the colonial government of the hook for its obstructionist policy towards social reforms in India nor failed to acknowledge the contribution of Indians themselves in addressing the issue of the child marriage.

Prior to Mayo and other intervention from the west In the early twentieth century, several Women's Journals in Hindi came in to being. Women's Journals was important to Women in several ways. First, they were the safest and the most immediately available place for even modestly educated women to went their views, encouraged by editors; they were the first place where women could acquire a public voice.

\footnotetext{
54 Stri Dharma, December 1929, pp.1-5

55 Mrinalini Sinha, op.cit, pp.1-61
}

Sharma, M. (2021). Emerging Female Voices and Child Marriage Reforms in Early Twentieth Century. International Journal of Historical Insight and Research, 7(1), 18-29.

https://doi.org/10.48001/ijhir.2021.07.01.003 
Second, they were effectively supplemented, even supplanted, when formal education was limited. Such articles were written by men in women's magazines.

Francesca Orsini distinguishes three broad phases of the growth and development of Journals in the Hindi Public Sphere. ${ }^{56}$

First, the Reformist phase in Nineteenth century,

Second, Radical - critical phase of early twentieth century,

Third, Post-Independence when Women Journals return to domestic concern.

The one of the most famous Journal during second phase was Stri-Darpan (Mirror of the women), run by the women of Nehru family. It Championed women's education, awakening of political rights, fought against gender discrimination. Compared to Grihalakshmi, Stri-Darpan covered a wider range of issues regarded as 'suitable for women'. Apart from articles against purdah, on historical examples of female excellence, on hygiene and h; health, it also carried articles against role-based education, news of women's achievements in India and abroad and of meetings of women's organisations, and compared women's awakening in Bengal and Punjab with the sluggishness, found in united provinces. Stri-Darpan carried critical comments on marriage debates like child marriage, Inter-caste marriages. Before the publication of Chand, it carried maximum numbers of Articles on the suffering of Widows. ${ }^{57}$

Apart from above mentioned two, other major Hindi literary magazines: Saraswati and Madhuri carried descriptive accounts of

\section{$56 \quad$ Francesca Orsini, 'Domesticity and Be-} yond: Hindi Women's Journals in the Early Twentieth Century', South Asia Research, 19, 2 (1999), pp. 137-60, idem; Hindi Public Sphere 1920 - 1940: Language and Literature in the Age of Nationalism, (New Delhi, Oxford University Press, 2002.)
Women from other parts of the world complete with photographs. The intention, however, was only too acquaint readers with matters of sociological interests and to give them access to varied materials. An another women-oriented magazine was Arya Mahila of sanatan dharma mahamandal, published from Banaras. It drew support for Women's rights not only from west but also from Indian past. Arya mahila demanded education and status for Indian women on the bases of Vedic ideals. ${ }^{58}$ However, 'Chand' directly serves the purpose of this paper.

Chand (The Moon) edited. by Ramrakh Singh Sahgal, was the most powerful and radical of all, revolutionised the female voices in U.P. it had been able to foster a feeling of identification between its readership and the Journal; identification was inclusive, addressing the concerns of all women,' from all over the country and from all social strata. In addition, Sahgal's attacks on the oppressive practices hallowed by tradition and by the most prominent Hindu social groups showed that no target was off-limits. Sahgal promoted a critical culture that valued bluntness and open- mindedness, a culture that valued women's work and self-reliance; in a word, that did not consider stability -- of the family, of society and of tradition -- the highest value of all ${ }^{59}$.

It willingly took on holy cows and taboos of all kinds and encouraged women to take a full part in the public sphere. Its first issue was exclusively on child marriage and Widowhood. However, the chief characteristic of this Journal was an introduction of the column of Letter to

Sharma, M. (2021). Emerging Female Voices and Child Marriage Reforms in Early Twentieth Century. International Journal of Historical Insight and Research, 7(1), 18-29.

https://doi.org/10.48001/ijhir.2021.07.01.003 
Editor that provided the first hand expression of Women's.

in this series Shri Satyabhakta wrote an article 'aagye badne ka awesur'" opportunity of progress" 60 in which Social reforms endeavours regarding women of late nineteenth and early twentieth century were the strong evidence of degradation in Hindu society in the last 500 years. It manifested the presence of credulities in Hindu society and Hindus were far aloof from true knowledge and yet to be civilized. ${ }^{61}$

The change in perception was the real solution of the problem. In the society. It is superfluous to waste hundreds of the year for small reform. The condition of women was not similar and varied community to community region to region. Therefore, any unequivocal reform was difficult to be made. Yet, freedom from religious or community boundaries were key to bring change in women's degraded condition in women in society. ${ }^{62}$

The child marriage abolition league was established under the auspicious of maharani of Mandi. This league recommended the minimum age of marriage as 16 for girls and as 18 for boys, which was higher then the age proposed by Sarda in central Legislative Assembly ${ }^{63}$.

The main objective of the league was to make and educate the public opinion of Indians against the institution of child marriage through active propaganda. In order to make league effective, an all-India committee was appointed of men and women from each state and state agencies had to form provincial committees. Similarly, provincial committees had to

\footnotetext{
60 Chand, April 1923, p. 473

61 Ibid.

62 Ibid.

63 Stri Dharma, September 1928,pp17-18

64 Ibid.

65 During British rule Simla was the capital of India in Summer.
}

form districts committees and urge the necessities of public meetings, lectures at schools and colleges, distributing literature, encouraged boys and girls, and similar organizations to go around singing propaganda songs ${ }^{64}$.

The league was financed by the means of donation and membership subscription of Rs 3/per month and for life membership Rs 100. The headquarters of all India child marriage abolition league was situated in Delhi and Shimla according to seasons ${ }^{65}$. The league explained the custom of child marriage "the child marriage devised like the race by obliging the girls and the boys to marry in early age ${ }^{66}$.

The child marriage abolition league was formed under (AIWC) but the royal women like Maharani of Mandi and Maharani ChimnaBai were active and played significant role. They asserted that the league would be led by none of outsider which led to a conflict between (AIWC) and the league. The suspicion on behalf of (AIWC)was mentioned by Smt. Kamala Devi Chattopadhyaya in her letter to Maharani of Mandi67.

This misunderstanding was soon cleared up by Rajkumari Amrit Kaur. she accepted the importance of (AIWC)in the formation and action of All India child marriage league. Obviously, no league could be formed in pursuance of the resolution passed at (AIWC) ${ }^{68}$

In a letter to Kamala Devi Chattopadhyaya, Amrit Kaur raised the following crucial issues :69

1. she asserted that an effective influential body had to be formed to carry and organize

\footnotetext{
66 Stri Dharma, December 1928,pp17

67 Kamala Devi Chattopadhyaya to Maharani Mandi, $15^{\text {th }}$ April 1928, AIWC Papers.

68 Raj Kumari Amrit Kaur to Kamala Devi Chattopadhyaya, $1^{\text {st }}$ July 1928, AIWC Papers 69 Ibid.
}

Sharma, M. (2021). Emerging Female Voices and Child Marriage Reforms in Early Twentieth Century. International Journal of Historical Insight and Research, 7(1), 18-29.

https://doi.org/10.48001/ijhir.2021.07.01.003 
national propaganda against child marriage on modern lines.

2. This body would have to make and appeal to both to government so as to gain as much and definite and active support as possible for its work and public at large; so as to bring not only 'extremely 'advanced section but the great mass which was' indifferent and, moderate'.

3. This body would further need large sums of money which was to be collected by itself, and to make its financial position legal, this collected money, would also to be controlled by itself. This fund could not be transferred to any other or any other general fund, legally.

4. Constitutionally women's organization were for women alone this subcommittees an integral part of (AIWC) necessarily feminine also. Therefore, a mixed subcommittee was not possible.

5. In view of the age question and that of other consideration such as the financial one and that of expediency and effectiveness in seemed wiser to her to make the league practically an independent organization.

Physical consideration formed the medical point of view that Kaur elaborated, suggested that it was unquestionably better to delay until the parties are physically formed until the purposes of child marrying.

Therefore, league decided to fix the minimum age of marriage for time being and which could not be argued against any point of view and which could give time to develop and educate the people up to the ideal and more enlightened standards. Hence, 16 for girls and 18 for boys was both morally and physiologically fit for both of them. However, the league took the compromising stand and recommended rather than desirable age of marriage education and economic considerations were bound up together. The league, she said designed its propaganda not only for upper class but poor class of the populations also. She was also aware of the problem that the poor's will have to face the problems in keeping their children in schools till 16 or 18 years of age. \

Some members like Deewan Bahadur Rangacharya and other activist members were in favour of 18 and 21 years as minimum age. Nevertheless, they reached the conclusion that it was difficult rather impossible to secure the support from the orthodox section with this proposition, hence, supported realism and compromise with Sarda's marriage Bill.

Indian female voice promoted this Legislation at every stage, generated propaganda, commented, petitioned, met with the Joshi Committee, lobbied to secure The CMRA and did every action to make this law successful or meaningful. Despite the shortcomings and limitations had been in Indian female voice precisely in in the beginning of twentieth century but they played meaningful role in the enactment of Sarda Act in October 1927.

(AIWC) led the groundwork to spread Sarda Act in the countryside since the female voice in India was mainly urban based and was not connected to rural areas. Besides, the single-issue organizations like All India child marriage abolition league might prove effective but it did not properly function because of its tensed relationship with (AIWC). So far as Mayo was concerned, the architect of this Act Sarda said that 'a few there are, however, who do not belong to India, and who are unhappy over the abolition of child marriage. there chief representative is Miss Mayo and they fear that when child marriage disappears their profession of ruling the country on which they flourish, shall have gone. By belittling the enormous importance of the new law, they betrayed to their hostility to the advancement of the country.'

Sharma, M. (2021). Emerging Female Voices and Child Marriage Reforms in Early Twentieth Century. International Journal of Historical Insight and Research, 7(1), 18-29.

https://doi.org/10.48001/ijhir.2021.07.01.003 